\title{
Tata laksana Pasien Gravida 29-30 Minggu dengan Gagal Napas ec. Hypokalemic Periodic Paralysis yang Diperberat dengan Community Acquired Pneumonia
}

\author{
Mariko Gunadi, ${ }^{1}$ Suwarman, ${ }^{2}$ Nurita Dian Kestriani ${ }^{2}$ \\ ${ }^{1}$ Rumah Sakit Santo Yusup Bandung \\ ${ }^{2}$ Departemen/KSM Anestesiologi dan Terapi Intensif \\ Fakultas Kedokteran Universitas Padjadjaran/Rumah Sakit Dr. Hasan Sadikin Bandung
}

\begin{abstract}
Abstrak
Penatalaksanaan sakit kritis pada wanita hamil memiliki karakteristik yang unik karena perubahan fisiologi selama kehamilan dan janin yang berkembang dalam uterus yang mendapat implikasi yang signifikan. Pada kasus ini, seorang perempuan 27 tahun yang sedang hamil gemeli usia kehamilan 29-30 minggu datang ke Instalasi Gawat Darurat (IGD) Rumah Sakit Dr. Hasan Sadikin Bandung dengan keluhan utama kelemahan keempat anggota gerak. Hasil pemeriksaan laboratorium didapatkan kadar kalium sangat rendah dan didiagnosis dengan hypokalemic periodic paralysis. Pasien mengalami gagal napas sehingga dilakukan intubasi dan diberikan bantuan ventilasi mekanik, kemudian dirawat di Intensive Care Unit (ICU). Gagal napas disertai penyulit community acquired pneumonia. Tata laksana ventilasi mekanik pada wanita hamil di ICU bersifat suportif dengan teknik sama seperti pada pasien tidak hamil, namun memiliki target khusus yang berbeda. Monitoring fetal heart rate (FHR) dapat mencerminkan kesejahteraan janin dan kondisi ibu. Tujuan penulisan laporan kasus ini adalah mengetahui pentingnya target pemberian ventilasi mekanik dan melakukan monitoring FHR pada pasien hamil di ICU.
\end{abstract}

Kata kunci: Gagal napas, gravida, hypokalemic periodic paralysis

\section{Management of Respiratory Failure Due to Hypokalemic Periodic Paralysis Complicated with Community Acquired Pneumonia in 29-30 Weeks of Gestation}

\begin{abstract}
Management of critically ill pregnant women in Intensive Care Unit (ICU) has unique characteristics due to the physiological changes during pregnancy and the presence of growing fetus in the uterine which may present significant implications. This study presented a case of a 27 years old woman with 29-30 weeks of gestation of twin pregnancy who came to Emergency Room (ER) with the chief complaint of weakness in both lower and upper extremities. Laboratory investigations showed a very low potassium level and the patient was diagnosed with hypokalemic periodic paralysis. Patient then experienced respiratory failure at the ER, intubated, and mechanically ventilated and was sent to the ICU. Community-acquired pneumonia was complicating the respiratory failure. Basically, mechanical ventilation management for pregnant patient in ICU is supportive in nature and uses the same techniques employed for the non-pregnant patient. However, the goals are different as it is important to monitor fetal heart rate (FHR) in pregnant woman as this does not only reflect the fetal well-being but also the maternal condition. This case report is intended to show the importance of mechanical ventilation goal and FHR monitoring in pregnant patients in ICU.
\end{abstract}

Key words: Hypokalemic periodic paralysis, pregnancy, respiratory failure

Korespondensi: Mariko Gunadi, dr., SpAn, KSM Anestesiologi dan Terapi Intensif Rumah Sakit Santo Yusup, Jl. Cikutra No. 7 Bandung, Tlpn. (022) 7202420, Faks. (022) 7202419, Email mariko_doc@yahoo.com 


\section{Pendahuluan}

Penyakit kritis yang menyebabkan wanita hamil membutuhkan perawatan Intensive Care Unit (ICU) merupakan kondisi yang jarang terjadi. ${ }^{1,2}$ Jumlah pasien hamil di ICU diperkirakan kurang dari 2\% dari seluruh pasien yang dirawat di ICU.,3 Gagal napas akut merupakan komplikasi pada kehamilan yang jarang terjadi, diperkirakan $0,1-0,2 \%$ ibu hamil mengalami gagal napas akut yang membutuhkan bantuan ventilasi mekanik. ${ }^{3}$

Ibu hamil memiliki karakteristik unik dikarenakan perubahan pada seluruh sistem tubuh (anatomi, fisiologi, dan biokimia). ${ }^{25,6}$ Penatalaksanaan gagal napas pada prinsipnya bersifat suportif dan tidak ada perbedaan dengan tata laksana ventilasi mekanik pada pasien tidak hamil, tetapi memiliki target khusus yang berbeda dikarenakan perubahan fisiologi sistem pernapasan. Keunikan lain adalah perlunya merawat dua orang pasien yang salah satunya adalah janin yang tidak dapat diakses secara langsung tetapi janin ini mengalami implikasi yang signifikan. ${ }^{7}$ Oleh karena itu, penting bagi intensivist untuk memahami perubahan yang normal terjadi selama kehamilan dalam rangka penatalaksanaan pasien hamil dengan sakit kritis di ICU dan melakukan monitoring kesejahteraan janin.

\section{Laporan Kasus}

Seorang wanita 27 tahun $\mathrm{G}_{2} \mathrm{P}_{1} \mathrm{~A}_{0}$ gravida gemeli 29-30 minggu dengan riwayat seksio sesarea 2 tahun yang lalu, datang ke instalasi gawat darurat (IGD) Rumah Sakit Dr. Hasan Sadikin Bandung dengan keluhan utama lemah keempat anggota gerak. Keluhan diawali dengan lemah kedua tungkai sejak 7 hari sebelumnya. Kedua paha terasa berat, namun masih dapat berjalan. Lama kelamaan bertambah berat sampai pasien tidak dapat berdiri dan berjalan saat satu hari sebelum masuk rumah sakit. Keluhan lemah pada kedua lengan, terutama pada lengan atas dirasakan sejak 3 hari sebelum masuk rumah sakit. Riwayat keluhan serupa sebelumnya tidak ada. Pasien tidak mengeluh kesulitan bernapas ataupun menelan dan masih dapat menggerakkan otot leher dan wajahnya. Pasien menyangkal terdapat nyeri atau baal. Sebelum terjadi kelemahan, pasien berada dalam kondisi sehat dan menyangkal mengalami diare, muntah, nyeri dada, atau sesak napas. Keluhan berdebar-debar tidak ada. Pasien tidak sedang mengonsumsi obat apapun selain vitamin untuk kehamilannya dan menyangkal mengonsumsi alkohol. Tidak ada perubahan aktivitas atau pola makan yang signifikan sebelumnya. Riwayat penyakit serupa pada anggota keluarga tidak ada.

Pada pemeriksaan fisis didapatkan kesadaran kompos mentis dengan tekanan darah 120/80 mmHg, laju nadi $104 \mathrm{x} /$ menit, laju napas 32-36 x/menit, saturasi oksigen $97 \%$ dengan udara bebas, tidak didapatkan ronki maupun wheezing, suhu $36,9^{\circ} \mathrm{C}$. Pemeriksaan neurologis menunjukkan penurunan kekuatan motorik kedua lengan (4 dari 5) dengan penurunan refleks fisiologis (1

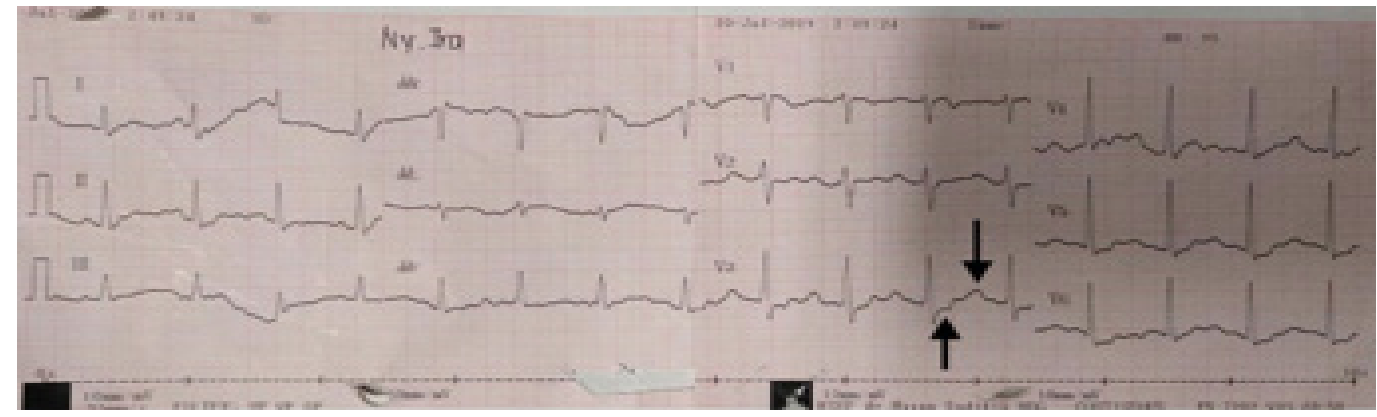

Gambar 1 Hasil Pemeriksaan EKG di IGD

Sumber: dokumentasi pribadi 


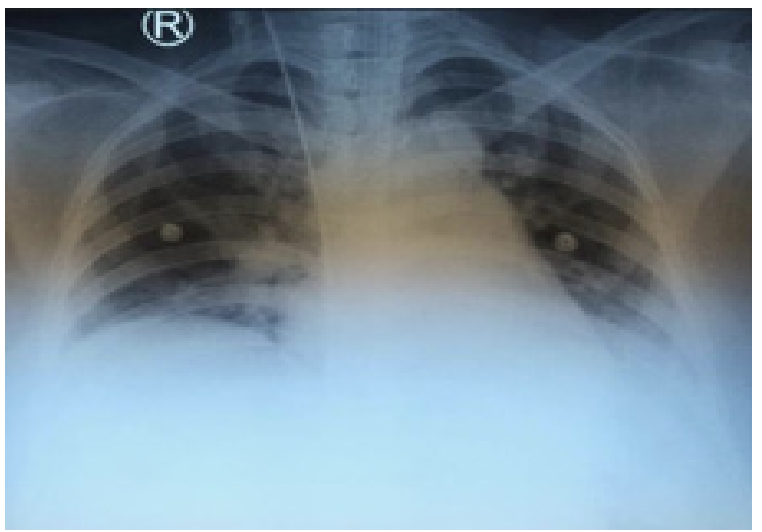

Gambar 2 Rontgen Toraks Hari Pertama di ICU Sumber: dokumentasi pribadi

dari 2) dan penurunan kekuatan motorik kedua tungkai (3 dari 5) dengan penurunan refleks fisiologis ( 0 dari 2), tidak ada refleks patologis dan rangsang meningeal, dan pemeriksaan saraf kranial dalam batas normal.

Hasil dari pemeriksaan laboratorium hemoglobin 9,6 g/dL, hematokrit 28,9\%, leukosit $10.770 \mathrm{~mm}^{3}$, trombosit $372.000 \mathrm{~mm}^{3}$, gula darah sewaktu $80 \mathrm{mg} / \mathrm{dL}$, ureum 10,0 $\mathrm{mg} / \mathrm{dL}$, kreatinin 0,48 mg/dL. Pemeriksaan elektrolit kalium 1,9 mEq/L dengan elektrolit lain dalam batas normal. Hasil analisa gas darah (AGD) arteri pH 7,41, $\mathrm{pCO}_{2}$ 30,2 mmHg, $\mathrm{pO}_{2} 100,5 \mathrm{mmHg}, \mathrm{HCO}_{3} 19,1 \mathrm{mmol} / \mathrm{L}, \mathrm{BE}$ $-4,1 \mathrm{mmol} / \mathrm{L}, \mathrm{SaO}_{2}$ 96,6\%. Pada gambaran elektrokardiografi (EKG) ditemukan depresi segmen ST dan gelombang U (Gambar 1). Pemeriksaan kesejahteraan janin didapatkan

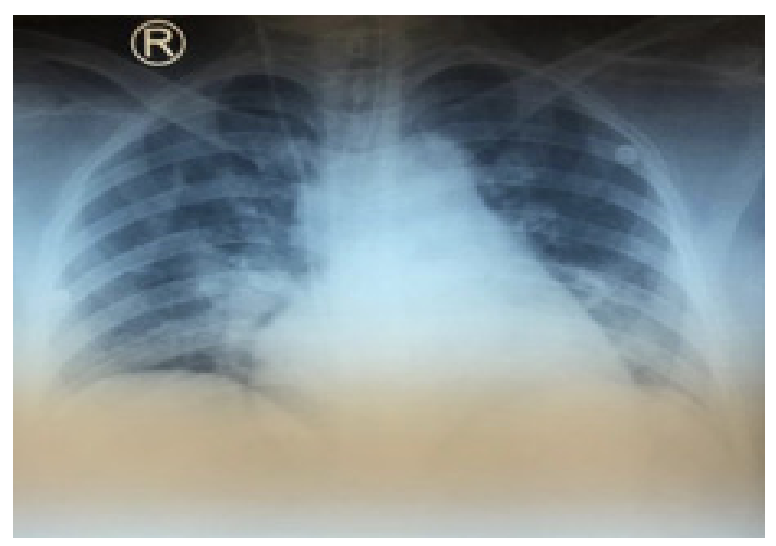

Gambar 4 Rontgen Toraks Hari Kelima di ICU Sumber: dokumentasi pribadi

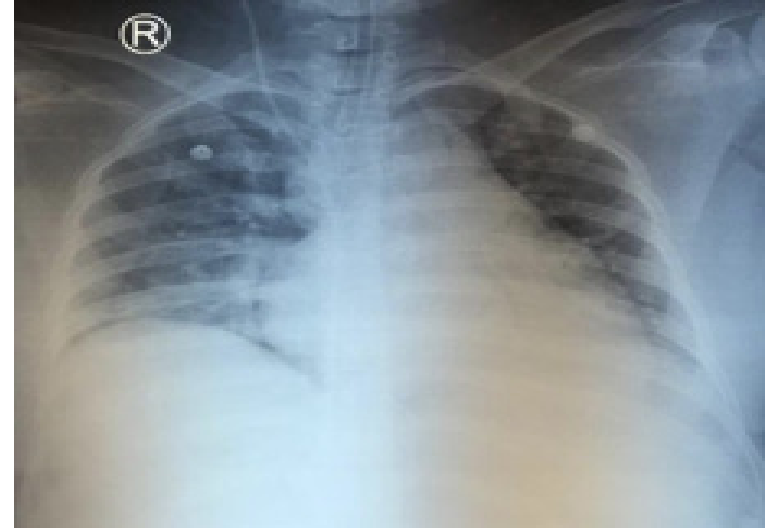

Gambar 3 Rontgen Toraks Hari Ketiga di ICU Sumber: dokumentasi pribadi

denyut jantung janin (DJJ) I 148-152 x/menit dan DJJ II 144-148 x/menit.

Pasien didiagnosis hypokalemic periodic paralysis (HPP) pada $\mathrm{G}_{2} \mathrm{P}_{1} \mathrm{~A}_{0}$ gravida gemeli 29-30 minggu. Pasien mendapatkan terapi koreksi hipokalemia dengan $\mathrm{KCl} 25 \mathrm{mEq}$ dalam Ringer laktat (RL) $500 \mathrm{~mL}$ selama 6 jam sebanyak 2 siklus. Setelah 8 jam masuk IGD pasien mengeluh sesak napas yang dirasakan semakin bertambah berat hingga laju napas mencapai 60x/menit dengan saturasi oksigen $92 \%$ menggunakan oksigen non-rebrething face mask (NRFM) $10 \mathrm{~L} /$ menit. Hasil pemeriksaan ulang AGD arteri pH 7,16, $\mathrm{pCO}_{2}$ 71,7 mmHg, $\mathrm{pO}_{2} 86,9 \mathrm{mmHg}, \mathrm{HCO}_{3} 25,8$ $\mathrm{mmol} / \mathrm{L}, \mathrm{BE}-3,5 \mathrm{mmol} / \mathrm{L}, \mathrm{SaO}_{2}$ 91,5\% dan
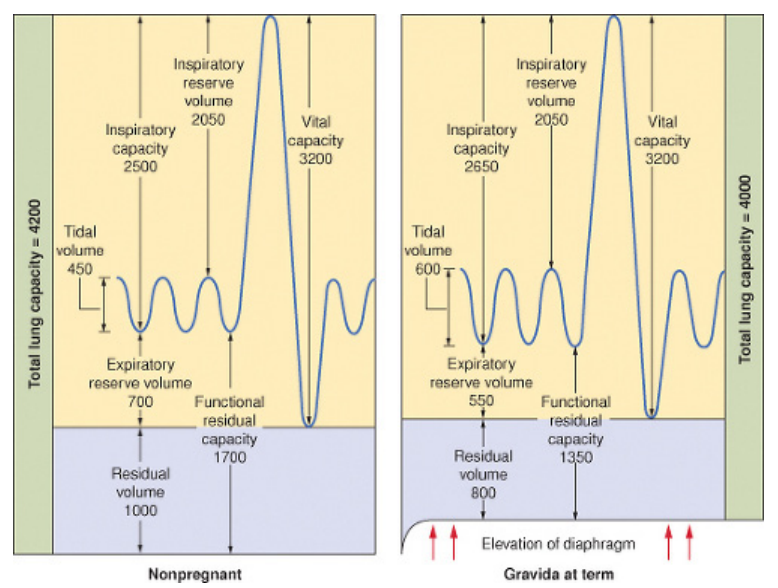

Gambar 5 Volume dan Kapasitas Paru Selama Kehamilan

Sumber: Bucklin dan Fuller. ${ }^{15}$ 
Tabel 1 Perubahan pada Volume Paru Selama Kehamilan

\begin{tabular}{ll}
\hline Perubahan volume paru & \\
\hline Total lung capacity & Berkurang $200-400 \mathrm{~mL}(4 \%)$ \\
Residual functional capacity & Berkurang $300-500 \mathrm{~mL}(17-20 \%)$ \\
Expiratory reserve volume & Berkurang $100-300 \mathrm{~mL}(5-15 \%)$ \\
Residual volume & Berkurang $200-300 \mathrm{~mL}(20-25 \%)$ \\
Inspiratory capacity & Bertambah $100-300 \mathrm{~mL}(5-10 \%)$ \\
Vital capacity & Tidak ada perubahan \\
Tidal volume & Bertambah sampai $150 \mathrm{~mL}(33 \%)$ \\
\hline
\end{tabular}

Sumber: Society of Critical Care Medicine. ${ }^{6}$

kalium 2,3 $\mathrm{mEq} / \mathrm{L}$. Diagnosis pasien berubah menjadi gagal napas ec. HPP pada $\mathrm{G}_{2} \mathrm{P}_{1} \mathrm{~A}_{0}$ gravida gemeli 29-30 minggu. Pemeriksaan DJJ I 164-168 x/menit dan DJJ II 162-166 x/ menit.

Pasien dipindahkan ke ruang resusitasi dan dilakukan intubasi, kemudian diberikan bantuan ventilasi mekanik dengan ventilator mode pressure support (PS) 16, positive end expiratory pressure (PEEP) 5, fraksi inspirasi oksigen $\left(\mathrm{FiO}_{2}\right) \quad 60 \%$ dengan volume tidal ekspirasi (VTe) 400-450 mL dan peak pressure (Ppeak) $21 \mathrm{cmH}_{2} \mathrm{O}$. Pasien mendapatkan sedasi dengan midazolam $3 \mathrm{mg} / \mathrm{jam}$. Hasil pemeriksaan AGD arteri setelah pasien mendapatkan bantuan ventilasi mekanik $\mathrm{pH}$ 7,39, $\mathrm{pCO}_{2} 35,4 \mathrm{mmHg}, \mathrm{pO}_{2} 172,8 \mathrm{mmHg}, \mathrm{HCO}_{3}$ $21,5 \mathrm{mmol} / \mathrm{L}, \mathrm{BE}-2,3 \mathrm{mmol} / \mathrm{L}, \mathrm{SaO}_{2} 98,1 \%$, rasio $\mathrm{pO}_{2} / \mathrm{FiO}_{2}(\mathrm{P} / \mathrm{F}) 288$ dan kalium 2,4 $\mathrm{mEq} / \mathrm{L}$. Pasien tenang dan kemudian sedasi

Tabel 2 Nilai Gas Darah Pasien Tidak Hamil dan Pasien Hamil

\begin{tabular}{lccc}
\hline & Tidak Hamil & Trimester Pertama & Trimester Ketiga \\
\hline $\mathrm{pH}$ & $7,35-7,45$ & $7,42-7,46$ & 7,44 \\
$\mathrm{PaO}_{2}, \mathrm{mmHg}$ & $90-100$ & 106 & $101-104$ \\
$\mathrm{PaCO}_{2}, \mathrm{mmHg}$ & $35-45$ & $28-29$ & $27-32$ \\
$\mathrm{HCO}_{3}, \mathrm{mEq} / \mathrm{L}$ & $22-26$ & 18 & $18-21$ \\
\hline
\end{tabular}

Sumber: Society of Critical Care Medicine. ${ }^{6}$
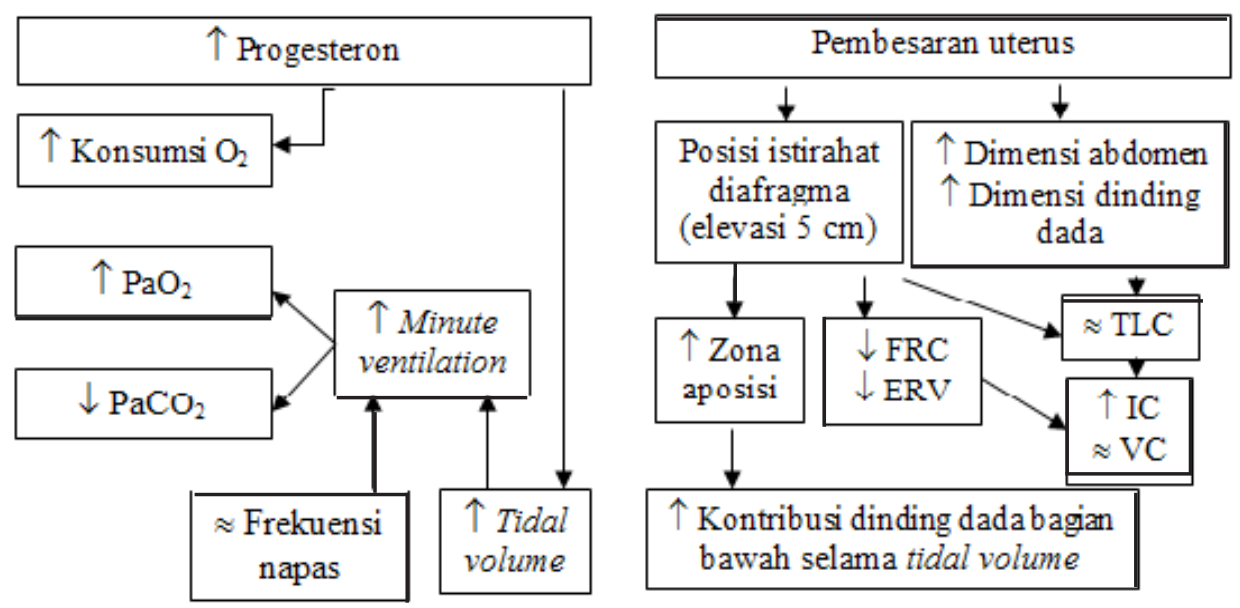

Gambar 6 Efek Biokimia dan Mekanik Kehamilan terhadap Perubahan Fungsi Paru Sumber: LoMauro dan Aliverti. ${ }^{16}$ 
dihentikan. Pasien kemudian dipindahkan ke ruang perawatan intensif (ICU).

Hari pertama di ICU pasien kembali menjadi sesak dengan laju napas 36-40 x/menit dan saturasi oksigen 89-92\% disertai demam dengan suhu $38,6{ }^{\circ} \mathrm{C}$, leukosit meningkat menjadi $14.730 / \mathrm{mL}$, dan rontgen toraks menunjukkan infiltrat paru kanan (Gambar 2). Hasil AGD arteri $\mathrm{pH} 7,41, \mathrm{pCO}_{2} 36,5 \mathrm{mmHg}$, $\mathrm{pO}_{2}$ 100,2 mmHg, $\mathrm{HCO}_{3} 22,9 \mathrm{mmol} / \mathrm{L}, \mathrm{BE} \mathrm{2,7}$ $\mathrm{mmol} / \mathrm{L}, \mathrm{SaO}_{2}$ 96,4\%, P/F 167.

Pasien kemudian didiagnosis gagal napas ec. HPP dan community acquired pneumonia (CAP) pada $\mathrm{G}_{2} \mathrm{P}_{1} \mathrm{~A}_{0}$ gravida gemeli 29-30 minggu. Mode ventilator diubah menjadi pressure synchronized intermittent mandatory ventilation (P-SIMV) 8, pressure control (PC) 18, PS 18, PEEP 8, $\mathrm{FiO}_{2} 70 \%$ dengan Vte 545-575 mL dan Ppeak 26-27 $\mathrm{cmH}_{2} \mathrm{O}$ dan diberikan terapi antibiotik ceftriaxone $1 \mathrm{x} 2 \mathrm{~g}$ dan antipiretik parasetamol 4x1 gr.

Pada hari pertama di ICU dilakukan pemeriksaan kultur dan resistensi darah dan sputum sebelum pemberian antibiotik. Urin mulai ditampung untuk pemeriksaan kalium urin 24 jam dan dilakukan pemeriksaan hormon tiroid.

Keluhan sesak pada hari kedua sampai keempat berkurang. Mode ventilator yang dipergunakan adalah mode PS. Weaning ventilator dilakukan bertahap dan pada hari keempat sudah mencapai PS 6, PEEP 5, $\mathrm{FiO}_{2}$ 50\% dengan Vte 500-550 mL dan Ppeak 11-12 $\mathrm{cmH}_{2} \mathrm{O}$. Pemeriksaan AGD dilakukan setiap hari dan hasil normal didapatkan pada hari kelima dengan $\mathrm{pH} 7,42, \mathrm{PCO}_{2} 31,3$ $\mathrm{mmHg}, \mathrm{PO}_{2} 133,4 \mathrm{mmHg}, \mathrm{HCO}_{3} 20,0 \mathrm{mmol} / \mathrm{L}$, BE $1,3 \mathrm{mmol} / \mathrm{L}, \mathrm{SaO}_{2} 97,8 \%, \mathrm{P} / \mathrm{F}$ 333. Pada hari kelima mode ventilator sudah menjadi CPAP PEEP 5, $\mathrm{FiO}_{2} 40 \%$ dengan Vte 450-550 $\mathrm{mL}$ dan Ppeak 6-7 $\mathrm{cmH}_{2} \mathrm{O}$. Pada hari keenam dilakukan spontaneous breathing trial (SBT) dengan menggunakan oksigen melalui T-piece $6 \mathrm{~L} /$ menit dan ekstubasi dilakukan pada hari ketujuh dengan hasil AGD arteri pH 7,40, $\mathrm{PCO}_{2}$ $30,4 \mathrm{mmHg}, \mathrm{PO}_{2} 100,1 \mathrm{mmHg}, \mathrm{HCO}_{3} 18,2$ $\mathrm{mmol} / \mathrm{L}, \mathrm{BE} \mathrm{0,6} \mathrm{mmol} / \mathrm{L}, \mathrm{SaO}_{2} 96,6 \%$.

Sampai hari kelima di ICU pasien masih mengalami periode demam dengan suhu tertinggi $38,5{ }^{\circ} \mathrm{C}$. Nilai leukosit meningkat menjadi $18.710 / \mathrm{mL}$ pada hari kedua, tetapi turun menjadi $16.120 / \mathrm{mL}$ pada hari keempat dan turun lagi menjadi $14.080 / \mathrm{mL}$ pada hari kelima. Hasil kultur darah tidak ditemukan pertumbuhan mikroorganisme, sedangkan hasil kultur dan resistensi sputum ditemukan Staphylococcus aureus yang masih sensitif dengan antibiotik ceftriaxone yang diberikan. Pemeriksaan rontgen toraks ulang pada hari ketiga (Gambar 3) dan hari kelima (Gambar 4) belum menunjukkan gambaran perbaikan pneumonia, walaupun secara klinis terjadi perbaikan. Hasil pemeriksaan kalium urin tampung 24 jam masih normal dengan nilai 15 $\mathrm{mmol} / 24$ jam dan hasil pemeriksaan hormon tiroid normal dengan T3 $0,9 \mathrm{ng} / \mathrm{mL}$, fT4 1,6 ng/dL, TSHs 0,3 mIU/mL.

Hari kedelapan didapatkan laju napas 20$24 \mathrm{x} /$ menit dengan saturasi oksigen 97-99\% menggunakan kanul nasal $3 \mathrm{~L} /$ menit, dan suhu 36,7-37,3 ${ }^{\circ} \mathrm{C}$. Pasien dipindahkan ke ruang rawat neurologi.

Selama perawatan di ICU pasien mendapatkan terapi koreksi hipokalemia menggunakan $\mathrm{KCl}$ disertai dengan pemberian maintenance $\mathrm{KCl} / 24$ jam. Kekuatan motorik kedua tungkai meningkat menjadi 4 dan refleks fisiologis tungkai meningkat menjadi 1 pada hari pertama di ICU dengan nilai kalium saat itu 2,5 mEq/L. Refleks fisiologis tungkai dan lengan kembali normal pada hari kedua di ICU dengan nilai kalium saat itu 2,7 mEq/L. Pada hari keenam kekuatan motorik kedua tungkai dan lengan menjadi normal dengan nilai kalium saat itu 2,9 mEq/L. Nilai kalium menjadi normal untuk ibu hamil pada hari ketujuh dengan nilai 3,3 mEq/L. Pada hari kedelapan nilai kalium 3,4 mEq/L dan terapi maintenance $\mathrm{KCl} / 24$ jam diganti dengan pemberian KSR 3x600 mg per oral.

Penilaian kesejahteraan janin dilakukan secara intermiten sebanyak 3 kali sehari menggunakan Doppler atau USG untuk menilai DJJ. Selama perawatan pasien di ICU, didapatkan takikardia pada janin dengan DJJ I dan DJJ II meningkat sampai 164-168 x/menit. Selama perawatan di ICU pasien mendapat infus RL $500 \mathrm{~mL} / 24$ jam dan diet cair dengan 
kebutuhan kalori bertahap dari 1.500 sampai 2.400 kkal. Produksi urin selama dirawat $>0,5-$ $1 \mathrm{~mL} / \mathrm{kgBB} / \mathrm{jam}$ dengan balans kumulatif (-) $2.778 \mathrm{~mL}$.

\section{Diskusi}

Pada kasus ini pasien didiagnosis hypokalemic periodic paralysis (HPP), yaitu kelemahan otot akut yang berhubungan dengan kadar kalium rendah. Tingkat kelemahan otot bervariasi mulai dari ringan, kelemahan hilang timbul, sampai kelemahan berat yang menyebabkan gagal napas. Terdapat banyak diagnosis banding penyebab kelemahan otot. Strok dan tumor yang menyebabkan kompresi saraf berpotensi mengancam jiwa dan harus disingkirkan terlebih dahulu. Penyebab lainnya adalah gangguan neuromuskular seperti myasthenia gravis dan Guillain-barre syndrome. Peridodic paralysis seperti HPP sering kali terlewatkan, namun secara klinis dapat ditegakkan setelah pemeriksaan kadar kalium serum. ${ }^{8,9}$ HPP perlu dipertimbangkan ketika dijumpai kelemahan atau kelumpuhan mendadak, terutama jika usia muda, tidak memiliki riwayat penyakit dan faktor risiko strok. ${ }^{8,10}$ Pemeriksaan hormon tiroid dapat membedakan antara HPP primer (idiopatik) dan HPP sekunder seperti thyrotoxic periodic paralysis. ${ }^{9}$

Kelemahan otot pada pasien ini sesuai dengan karakteristik HPP, yaitu kelemahan lebih dominan pada tungkai dibanding dengan lengan, bagian proksimal lebih dominan dibanding dengan distal. ${ }^{11}$ Refleks fisiologis turun atau hilang, tidak ada gangguan sensorik dan kesadaran karena permasalahan utamanya pada kontraksi otot, bukan pada konduksi saraf. ${ }^{8,11}$ Nilai kalium normal ibu hamil adalah 3,3-5,1 mEq/L, sedangkan pada pasien ini nilainya sangat rendah $(1,9 \mathrm{mEq} / \mathrm{L})$ sehingga terjadi kelemahan otot akibat hiperpolarisasi membran sel..$^{12,13}$

Koreksi kadar kalium didalam serum akan memperbaiki kelemahan otot. ${ }^{8,9}$ Oleh karena itu, pasien diberikan terapi $\mathrm{KCl}$ untuk mengembalikan kadar normal kalium serum. Ketika koreksi hipokalemia berjalan, pasien mengalami gagal napas akut karena HPP berkembang melibatkan kelemahan otot pernapasan. Perubahan fisiologi pernapasan yang normal pada ibu hamil akan terganggu akibat kelemahan otot pernapasan.

Perubahan fisiologi pernapasan ibu hamil disebabkan oleh efek kerja hormon dan perubahan fisik dan mekanik akibat dari pertumbuhan uterus. ${ }^{2,6}$ Progesteron meningkatkan laju metabolik sebanyak 15\% dan konsumsi oksigen sebanyak 20\% sehingga kebutuhan oksigen akan meningkat selama kehamilan. ${ }^{14}$ Tidal volume (VT) dan minute ventilation meningkat karena efek stimulasi progesteron itu pada pusat pernapasan., 2,5 Elevasi diafragma menyebabkan penurunan functional residual capacity (FRC), tetapi pergerakannya tidak berubah sehingga vital capacity tidak berubah. ${ }^{6,14}$ Sudut subkostal melebar sehingga lingkar dada bagian bawah bertambah. Akibatnya, total lung capacity (TLC) hanya berkurang 5\% karena penurunan residual volume sebesar $20 \%$. Lung compliance tidak berubah, tetapi chest wall compliance berkurang mengakibatkan total respiratory compliance sedikit turun. ${ }^{1,2}$ Perubahan volume dan kapasitas paru selama kehamilan dapat dilihat pada Tabel 1 dan Gambar 5.

Minute ventilation adalah VT dikalikan laju napas. Sebagian besar perubahan pada minute ventilation disebabkan oleh peningkatan VT, sedangkan laju napas meningkat sedikit sehingga terdapat takipneu sering menjadi tanda suatu proses patologis. ${ }^{1,2,5,6,14}$ Minute ventilation meningkat lebih banyak dibanding dengan peningkatan kebutuhan metabolik sehingga terjadi alkalosis respiratorik ringan yang terkompensasi (pH 7,40-7,47)., ${ }^{1,2,6,14}$ $\mathrm{PaCO}_{2}$ turun (28-32 $\mathrm{mmHg}$ ) dan nilai yang normal seperti pada kondisi tidak hamil $(\sim 40$ $\mathrm{mmHg}$ ), signifikan menunjukkan gagal napas dalam kehamilan. 2,6,14 Kompensasi ginjal untuk alkalosis respiratorik kronik adalah penurunan kadar bikarbonat (18-21 $\mathrm{mEq} / \mathrm{L})$. Hiperventilasi juga akan meningkatkan $\mathrm{PaO}_{2}$ (100-105 mmHg). ${ }^{5,6,14}$ Nilai normal gas darah pasien hamil dan tidak hamil dapat dilihat pada Tabel 2.

Pemeriksaan AGD pada pasien sebelum 
terjadi gagal napas menunjukkan alkalosis respiratorik kronik yang terkompensasi dengan $\mathrm{pH} 7,41, \mathrm{pCO}_{2} 30,2 \mathrm{mmHg}, \mathrm{HCO}_{3}$ 19,1 $\mathrm{mEq} / \mathrm{L}$, dan $\mathrm{pO}_{2}$ yang meningkat $100,5 \mathrm{mmHg}$. Hasil AGD ini sesuai dengan perubahan fisiologi sistem pernapasan yang normal pada ibu hamil (Gambar 6).

Kelemahan otot pernapasan karena HPP menyebabkan gangguan ventilasi. Pasien bernapas dengan VT yang rendah sehingga tidak terjadi peningkatan ventilasi (VT) yang normal sesuai dengan perubahan fisiologi pernapasan ibu hamil. Akibatnya, terjadi asidosis respiratorik akut dengan $\mathrm{pH} 7,16$, $\mathrm{pCO}_{2}$ 71,7 mmHg, dan $\mathrm{HCO}_{3} 25,8 \mathrm{mEq} / \mathrm{L}$. Setelah didiagnosis dengan gagal napas, pasien segera diintubasi dan diberikan bantuan ventilasi mekanik. Secara umum, teknik ventilasi mekanik pada ibu hamil dengan gagal napas sama dengan teknik untuk pasien tidak hamil, tetapi perlu diingat bahwa target gas darah arteri berbeda pada kondisi hamil. Peningkatan ventilasi yang menyertai kehamilan menghasilkan alkalosis respiratorik dan respons kompensasi metaboliknya. Dengan demikian, penting menjaga $\mathrm{PaCO}_{2}$ ibu dalam batas normal 28-32 mmHg. ${ }^{1,3}$

Pemakaian batas normal $\mathrm{PaCO}_{2}$ pasien tidak hamil (35-45 $\mathrm{mmHg}$ ) sebagai target ventilasi pada pasien hamil memiliki dampak buruk terhadap janin. $\mathrm{PaCO}_{2}$ normal janin pada vena umbilikal mendekati $42 \mathrm{mmHg}$. Peningkatan $\mathrm{PaCO}_{2}$ ibu akan menurunkan transfer $\mathrm{CO}_{2}$ melalui fetal-maternal $\mathrm{CO}_{2}$ transplacental gradient sehingga terjadi fetal acidemia. Transfer $\mathrm{CO}_{2}$ melalui plasenta bergantung pada perbedaan $\mathrm{PaCO}_{2} 10 \mathrm{mmHg}$ yang relatif konstan antara janin dan ibu. Oleh karena itu, hiperkapnia pada ibu dengan cepat menyebabkan asidosis respiratorik pada janin. . $, 5,6,14$ Perubahan fetal heart rate (FHR) yang meningkat (DJJ I 164-168 x/menit dan DJJ II 162-166 x/menit) pada kasus ini merupakan tanda dari fetal acidemia. $\mathrm{PaO}_{2}$ normal janin pada vena umbilikal relatif rendah mendekati $35 \mathrm{mmHg}$, tetapi oxygen content yang cukup dipertahankan oleh pergeseran kurva disosiasi oksigen janin ke kiri. Asidosis akan menggeser kurva disosiasi oksigen janin ke kanan, membatasi kemampuan hemoglobin janin untuk mengikat oksigen. ${ }^{1}$

Permissive hypercapnia sedapat-dapatmua dihindari ketika memberikan ventilasi pada ibu hamil. ${ }^{1,3}$ Bilamana diperlukan, permissive hypercapnia dengan $\mathrm{pCO}_{2}$ sampai $60 \mathrm{mmHg}$ masih dimungkinkan asalkan dengan kontrol pH ibu $(7,25-7,35)$ dan oksigenasi yang adekuat. ${ }^{4,5}$ Hiperventilasi juga harus dihindari karena alkalosis respiratorik yang menetap ( $\mathrm{pH}>7,48)$ dapat menyebabkan arteri uterina mengalami vasokonstriksi dan menurunkan perfusi janin. ${ }^{2-5}$

Manajemen ventilasi menggunakan ARDS network secara umum dapat digunakan. VT normal dalam kehamilan lebih besar daripada nilai target $6 \mathrm{~mL} / \mathrm{kg}$ predicted body weight (PBW) yang digunakan dalam ARDS network. Untuk mempertahankan peningkatan ventilasi yang normal menyertai kehamilan, laju napas dapat ditingkatkan. Jika tidak cukup untuk mencegah hiperkapnia, peningkatan VT harus dipertimbangkan. ARDS network membatasi maximum plateau pressure (Pplat) sampai 30 $\mathrm{cmH}_{2} \mathrm{O}^{1,2}$ Pada kondisi tidak ada gangguan lung compliance, penurunan chest wall compliance pada pasien hamil memungkinkan Pplat yang lebih tinggi $\left(>30 \quad \mathrm{cmH}_{2} \mathrm{O}\right)$ tanpa melebihi tekanan distensi transpulmonal. Penurunan lung compliance pada acute lung injury menjadi penentu utama total respiratory compliance. Karena alasan ini, batas Pplat $30 \mathrm{~cm} \mathrm{H}_{2} \mathrm{O}$ dari ARDS network dipergunakan. ${ }^{1,2,4,5}$

Pengantaran $\mathrm{O}_{2}$ kepada janin dipengaruhi oleh maternal arterial oxygen content dan uterine blood flow. 2,5 Rekomendasi $\mathrm{PaO}_{2}$ ibu adalah >70-75 $\mathrm{mmHg}$, yang berhubungan dengan $\mathrm{SpO}_{2}$ 95\% pada ibu, untuk melindungi janin dari cedera hipoksia. ${ }^{2-4}$

Ventilasi mekanik pada pasien ini menggunakan mode PS mempunyai tujuan meningkatkan kembali ventilasi (VT) sesuai dengan perubahan fisiologi hamil yang normal. Predicted body weight (PBW) berdasar tinggi badan pasien ini adalah 51 kg sehingga target VT adalah $400-550 \mathrm{~mL}$ (33\% lebih besar dari 6-8 mL/kg PBW). VT ini digunakan untuk mencapai target $\mathrm{pCO}_{2}$ 28-32 mmHg dengan batas Pplat $30 \mathrm{cmH}_{2} \mathrm{O}$. 
Untuk menjamin oksigenasi pada ibu dan anak, diberikan PEEP dan $\mathrm{FiO}_{2}$ terendah yang dapat mempertahankan $\mathrm{pO}_{2}>70-75 \mathrm{mmHg}$ atau $\mathrm{SpO}_{2}$ 95\%.

Mencari penyebab hipokalemia penting dilakukan sebagai upaya mencegah kelemahan berulang kembali. ${ }^{12,13}$ Pemeriksaan kalium urin 24 jam pasien dengan hasil $15 \mathrm{mmol} / 24$ jam menunjukkan hipokalemia tidak disebabkan oleh renal loss. Penyebab hipokalemia karena gastrointestinal loss juga dapat disingkirkan karena dari anamnesis tidak ada riwayat atau keluhan gangguan saluran cerna seperti muntah dan diare. Perpindahan intraseluler kalium seperti pemakaian insulin, stimulasi sistem saraf simpatis (albuterol, terbutalin), tirotoksikosis, dan paralisis periodik familial juga dapat mengakibatkan hipokalemia. ${ }^{12,13}$ Pemeriksaan hormon tiroid dalam batas normal dan pasien tidak menggunakan obat insulin ataupun obat asma. Oleh karena itu, hipokalemia pada pasien adalah suatu HPP primer (idiopatik atau familial). ${ }^{10,11,17}$

HPP bukan merupakan penyakit yang berhubungan dengan kehamilan sehingga HPP tidak menjadi indikasi terminasi kehamilan. Pemberian steroid dapat mencetuskan HPP. Oleh karena itu, jika ada indikasi terminasi kehamilan pada ibu hamil dengan riwayat HPP, pemberian steroid untuk pematangan paru janin harus benar-benar dipertimbangkan. ${ }^{8}$ Pada kasus ini usia kehamilan baru 29-30 minggu dan tidak ada indikasi terminasi kehamilan, sehingga pasien tidak mendapatkan terapi steroid.

Hari pertama di ICU pasien mengalami sesak napas kembali disertai demam $38,6{ }^{\circ} \mathrm{C}$, tidak ada batuk, ada produksi sputum kental warna putih, tetapi tidak produktif, tidak ada ronki dan wheezing di kedua lapang paru, dan leukosit meningkat menjadi 14.730/ $\mathrm{mL}$, rontgen toraks menunjukkan infiltrat paru kanan sehingga pasien didiagnosis juga dengan CAP. Gagal napas karena HPP pada pasien diperberat dengan CAP. Pneumonia adalah infeksi non-obstetrik paling sering dialami ibu hamil. Faktor risiko pneumonia pada kehamilan adalah anemia, asma, pemberian kortikosteroid antepartum untuk pematangan paru janin, dan penggunaan tokolitik. ${ }^{18-20}$ Faktor risiko pneumonia pada pasien ini adalah anemia dengan hemoglobin 9,6 g/dL $(<10 \mathrm{~g} / \mathrm{dL})$.

Pneumonia berpotensi dapat menyebabkan gangguan oksigenasi pada ibu dan bayi. Pada saat didiagnosis $\mathrm{CAP}$, rasio $\mathrm{P} / \mathrm{F}$ turun dari sebelumnya 288 menjadi 167. Selain itu, pneumonia juga dapat menyebabkan penurunan lung compliance yang memengaruhi pemberian ventilasi mekanik. Pada pasien ini oksigenasi dapat terjaga dengan baik dan mencapai target oksigenasi pada ibu hamil. Lung compliance juga masih cukup baik dengan Pplat yang tidak mencapai $30 \mathrm{cmH}_{2} \mathrm{O}$.

Pemilihan jenis antibiotik sama seperti pasien tidak hamil, tetapi sedapat-dapatnya menghindari penggunaan fluoroquinolon dan aminoglikosida. Fluoroquinolon dapat menyebabkan malformasi kongenital dan gangguan pertumbuhan kartilago, sedangkan aminoglikosida dapat menyebabkan gangguan saraf pendengaran dan gangguan ginjal. ${ }^{18-20}$ Pada pasien ini diberikan antibiotik tunggal ceftriaxone karena tidak ada faktor risiko multidrug resistant pathogens dan pneumonia tidak termasuk pneumonia berat dengan skor CURB-65 1 dan pneumonia severity index (PSI) class 1 (skor 0-50). Pemberian ceftriaxone memberikan hasil perbaikan klinis yang baik walaupun tidak ada perbaikan gambaran pneumonia pada rontgen toraks. Selain itu, pemeriksaan kultur resistensi sputum didapatkan kuman masih sensitif terhadap ceftriaxone.

Monitoring janin memiliki fungsi penting sebagai indikator perfusi end-organ (unit fetoplasental) karena memberikan petunjuk status janin dan secara tidak langsung mencerminkan kondisi ibu dan menjadi dasar dalam memodifikasi terapi. Oleh karena itu, penilaian status janin menjadi penting dalam penatalaksanaan ibu hamil di ICU. ${ }^{7}$

Selama pemberian ventilasi mekanik, perlu dievaluai FHR setiap hari. ${ }^{2}$ FHR dapat dimonitor secara intermiten atau kontinu, dan pemeriksaan non-invasif menggunakan Doppler atau cardiotocography (CTG) atau USG. FHR mencerminkan oksigenasi dan 
status asam basa janin. Baseline normal, variabilitas moderat, akselerasi dan tidak deselerasi merupakan prediktor yang baik untuk oksigenasi yang normal pada janin. ${ }^{7}$

Pada kasus ini dilakukan monitoring FHR setiap hari dan pada beberapa pemeriksaan didapatkan peningkatan FHR di atas baseline rate atau fetal tachycardia. Walaupun fetal tachycardia dapat merupakan manifestasi dari hipoksemia atau anemia janin, tetapi lebih sering dikarenakan demam atau pemberian obat yang bersifat simpatomimetik pada ibu. ${ }^{7}$ Penyebab lain fetal tachycardia adalah fetal acidemia, maternal sepsis, hyperthyroidism, maternal anemia, dan chorioamnionitis.

Keterbatasan pada pemeriksaan FHR menggunakan doppler atau USG pada pasien ini adalah hanya mengetahui nilai baseline rate. Sebaiknya penilaian FHR di ICU menggunakan CTG untuk mengetahui variabilitas, akselerasi, dan deselerasi sehingga dapat membedakan kemungkinan penyebab perubahan FHR yang akan membantu menentukan terapi atau tindakan pada ibu. Pada kasus ini fetal tachycardia yang terjadi selama perawatan di ICU berhubungan dengan demam pada ibu dan tidak disebabkan oleh hipoksia karena oksigenasi pada ibu terjaga dengan baik, $\mathrm{pO}_{2}$ dijaga di atas 70-75 mmHg dan $\mathrm{SpO}_{2}$ di atas $95 \%$. Terapi ditujukan untuk mengatasi demam dengan pemberian antipiretik dan antibiotik untuk mengatasi infeksi.

Fetal tachycardia ketika gagal napas akut sebelum masuk ICU berhubungan dengan fetal acidemia karena asidosis respiratorik akut pada ibu. Tata laksana ditujukan untuk mengatasi asidosis respiratorik akut dengan memberikan dukungan ventilasi mekanik untuk membantu ventilasi dan/atau oksigenasi yang terganggu karena HPP.

\section{Simpulan}

Penatalaksanaan ibu hamil yang mengalami gagal napas karena HPP yang diperberat dengan CAP memerlukan perhatian khusus karena terjadi perubahan fisiologi sistem pernapasan dan terdapat janin yang berkembang. Tata laksana ventilasi mekanik pada ibu hamil dengan gagal napas tidak berbeda dengan pasien tidak hamil, tetapi memiliki target khusus yang berbeda. Fetal monitoring merupakan bagian penting dari perawatan ibu hamil di ICU karena tidak hanya menunjukkan kondisi janin, tetapi juga kondisi ibu sehingga dapat ikut membantu menentukan terapi atau tindakan pada ibu.

\section{Daftar Pustaka}

1. Campbell LA, Klocke RA. Implications for the pregnant patient. Am J Respir Crit Care Med. 2001;163:1051-4.

2. Bhatia PK, Biyani G, Mohammed S, Sethi P, Bihani P. Acute respiratory failure and mechanical ventilation in pregnant patient: a narative review of literature. J Anaesthesiol Clin Pharmacol. 2016 OctDec;32(4):431-9.

3. Clardy PF, Reardon CC. Acute respiratory failure during pregnancy and the peripartum period. [diunduh 23 Februari 2018]. Tersedia dari: http://www. uptodate.com.

4. Schwaiberger D, Karcz M, Menk M, Papadakos PJ, Dantoni SE. Respiratory failure and mechanical ventilation in the pregnant patient. Crit Care Clin. 2016; 32:85-95.

5. Lapinsky SE, Calleja JGP, McCullagh I. Clinical review: ventilatory strategies for obstetric, brain-injured and obese patients. Crit Care. 2009;13(2):206.

6. Society of Critical Care Medicine. Physiologic changes during pregnancy. Fundamental Critical Care Support: Obstetrics. 2017;1. hlm. 1-10.

7. Society of Critical Care Medicine. Fetal evaluation and fetal concerns in the seriously ill pregnant patient. Fundamental Critical Care Support: Obstetrics. 2017;9. hlm. 113-36.

8. SouleBR, Simone NL. Hypokalemic periodic paralysis: a case report and review of the literature. Cases J. 2008;1:256.

9. Abdullah HMA, Shahzad MA, Raza SS, Hussain AK, Nadeem MD. Hypokalemic periodic paralysis: a case report. Imperial J 
Interdiscipl Res. 2016;2(5):1341-3.

10. Kibe R, Biniwale N, Biniwale A. Hypokalemic periodic paralysis: a case report. Int J Res Med Sci. 2017 Jun;5(6):2794-6.

11. Rodriguez EDM, Rojas VEF. Case report: recurrent hypokalemic periodic paralysis associated with distal renal tubular acidosis (type 1) and hypothyroidism secondary to Hashimoto's thyroiditis. F1000Research. 2019;7:1154.

12. Kardalas E, Paschou SA, Anagnostis P, Muscogiuri G, Siasos G, Vryonidou A. Hypokalemia: a clinical update. Endocrine Connections. 2018;7:R135-46.

13. Marino PL. Renal and electrolyte disorders: potassium. The ICU Book. 2014;36:67386.

14. Pillay PS, Piercy CN, Tolppanen H, Mebazaa A. Physiological changes in pregnancy. Cardiovasc J Afr. 2016 March/ April;27(2):89-94.
15. Bucklin BA, Fuller AJ. Physiologic changes of pregnancy. Anesthesia key 2016 [diunduh 16 September 2016]. Tersedia dari: http://www.aneskey.com

16. LoMauro A, Aliverti A. Physiology masterclass: respiratory physiology of pregnancy. Breathe. 2015;11:297-301.

17. Kulkarni M, Srividya TV, Gopal N. Hypokalemic paraplegia in pregnancy. J Clin Diagn Res. 2014 Jun;8(6):OD03-4.

18. Lim WS, Macfarlane JT, Colthorpe CL. Pneumonia and pregnancy. Thorax. 2001;56:398-405.

19. Khan S, Niederman MS. Pneumonia in the pregnant patient. Pulmonary problems in pregnancy, respiratory medicine. 2009;13:177-95.

20. Goodnight WH, Soper DE. Pneumonia in pregnancy. Crit Care Med. 2005;33(10) (Suppl):S390-7. 